\title{
Kişilerarası Psikoterapi ve Kişilik \\ Organizasyonlarının Entegrasyonu: Majör Depresif \\ Bozukluk Vakasının Gözden Geçirilmesi
}

\author{
Tuğba Yılmaz* \\ Orta Doğu Teknik Üniversitesi
}

\begin{abstract}
Özet
Majör depresif bozukluk; davranışsal, duygulanımsal, bilişsel ve bedensel semptomları içerir. Günümüzde ruh hastalıklarının sınıflandırılmasında tıbbi yaklaşıma önem verilmektedir; ancak hastalıkların nedenlerini bütüncül olarak anlayabilmek için erken dönem deneyimlerin ele alınması gereklidir. Kişilerarası Psikoterapi (KPT) erken dönem yaşantılara odaklanır ve kaygı dinamikleri üzerine vurgu yapar. İlk kişilerarası deneyim olan anne ve bebek arasındaki duygusal uyumun kaygı ile başa çıkma üzerinde önemli bir etkisi vardır. KPT, annenin çocuğun kaygı tansiyonunu rahatlatması ve ihtiyaç gerilimini doyurması gerektiğini öne sürer. Eğer bu olmaz ya da kötücül yollarla olur ise, çocuğun bir bağlanma problemi olan kopmayı yaşaması beklenmektedir ve bu durumun ileriki yaşlarda psikolojik bozukluklara yol açabileceği öngörülmektedir. Bir hastadaki semptomların şiddeti süreğen kişilik özellikleri ile de ilgilidir; ancak KPT bunu ele almaz. $\mathrm{Bu}$ amaçla, psikanalitik yaklaşımda ele alınan kişilik organizasyonu çeşitleri, KPT ile entegre edilmiştir. Buna göre nevrotik, sınır durum ve psikotik kişilik organizasyonları bulunmaktadır. Sınır durum örgütlenmiş kişilikler, şiddetli bir kaygı durumunda psikotik olanlara benzer şekilde davranırlar. Bu çalışmada, majör depresif bozukluğu ve psikotik semptomları olan bir vaka ele alınmıştır. İlgili vaka, erken dönem yaşantıları ve güncel kritik olayları çerçevesinde sunulmuştur. Vaka formülasyonu ve tedavi süreci iki teorinin entegre edilmesi ile detaylandırılmıştır. Son olarak, terapötik çıkarımlar tartışılmıştır.
\end{abstract}

Anahtar kelimeler: Majör depresif bozukluk, Kişilerarası psikoterapi, Kişilik organizasyonu

*İletişim: tugba.yilmaz.psy@ gmail.com

Başvuru tarihi: 06.01.2016

Kabul tarihi: 22.06.2016 


\section{Kişilerarası Psikoterapi ve Kişilik Organizasyon Çeşitlerinin Entegrasyonu: Majör Depresif Bozukluk Vakasının Gözden Geçirilmesi}

\section{Bir Tanı Olarak Depresyon}

Depresyon, tek uçlu duygu durum bozuklukları altında "Majör depresif bozukluk" adı ile sınıflandırılmış bir psikopatolojidir (American Psychiatric Association [APA], 2000). DSM-5' in ortaya çıkması ile sınıflandırıldığı grup değişmiştir. DSM'nin bu son versiyonunda majör depresif bozukluk (MDB), "Depresif Bozukluklar" grubuna dâhil edilmiştir (APA, 2013).

MDB, günün çoğunda süregelen depresif duygu durumu, aktivitelere duyulan ilginin azalması ve aktivitelerden alınan zevkin azalması, kilo kaybı ya da kilo alma, iştahta artış ya da azalma, uykusuzluk ya da aşırı uyuma, psikomotor uyarılma ya da gerileme, yorgunluk ve enerji kaybı, değersizlik hisleri, aşırı ya da uygunsuz suçluluk hisleri, düşünme ve konsantre olmada güçlük, kararsızlık ve yinelenen ölüm düşünceleri ile belirlenmiştir (APA, 2013). Diğer ruh hastalıklarında olduğu gibi, MDB klinik boyutta stres ya da sosyal, mesleki ya da diğer işlev alanlarında bozukluk yaratma yolu ile tanı olarak koyulabilir.

DSM, ruh hastalıklarının tedavisi alanındaki gelişmeler ve koşullara göre gözden geçirilerek düzenlenmektedir. DSM-IV-TR ile DSM-5 arasındaki büyük bir değişiklik, çok eksenli sınıflandırmanın iptal edilmesidir. Çok eksenli sınıflandırma ile DSM daha çok ruh hastalıkları için biyopsikososyal bakış açısına sahipti. Örneğin, bir psikolog tanı ve tedaviyi etkileyebilecek olan psikososyal ve çevresel problemleri Eksen 4'te belirtebilmekteydi (Oltmanns \& Emery, 2006). Bu nedenle, DSM'ye göre yapılan sınıflandırmaların daha çok ruh hastalıkları için tıbbi yaklaşıma dayanmaktadır. Diğger bir deyişle, ruh hastalıklarının semptomlardan oluştuğu düşünülmektedir ve bu semptomların nedenleri ve gerekçeleri odak dişında tutulmuştur.

Ruh hastalıklarının ve anormal davranışın açıklanmasında tıbbi bakış açısına sahip olan DSM temelli değerlendirme yerine bilinçdışı güçlerin etkisini vurgulayan psikanalitik bakış açısı da kullanılabilir (Plante, 2005). Freud, depresif semptomları, hayatlarında önemli birisini kaybeden insanların duygularında araştırmıştır ve çalışmasını "Yas ve Melankoli" adlı kitabında paylaşmıştır (1917). Freud hem depresif duygu durumunda, hem de kayıp sonrası oluşan yasta temel duygunun üzüntü olduğunu vurgulamıştır ancak iki durumun arasındaki farkları da incelemiştir. Freud'a göre yastaki üzüntünün nedeni dış dünyada sevilen birinin artık eksik olmasıdır. Öte yandan, depresif semptomlardaki üzüntü ise kişinin kendiliğinden bir parça kaybetmesi ya da kendiliğinin yaralanması şeklindeki bir düşünceyle ilişkilidir (1917).

Gözlemlerine dayanarak, Freud (1917) depresyonun önemli bir öncülünün yaşamın erken dönemlerinde gerçekleşmiş bir kayıp deneyimi olduğunu söyler. Bu kayıp deneyimi önemli bir kişinin ölümü gibi gerçek bir kayıp deneyimi olabileceği gibi, önemli gelişimsel ihtiyaçlardan mahrum kalınması anlamına da gelebilir. Psikanalitik literatürde tartışılan başka bir düşünce de depresif kişilerin erken yaşam olaylarında kendi uyum seviyelerini aşan bir tür hayal kırıklığı yaşamış olabileceği düşüncesidir (Fenichel, 1945) ve bu düşünce Freud'un önermesi ile benzerlik göstermektedir.

Psikanalitik görüş depresif kişilerin insanlardan ayrılma düşüncesinin kendilerine zor gelmesi nedeni ile olumsuz duygularını diğer kişilerden uzak tuttuğunu belirtmektedir. Bu olumsuz hisleri daha çok kendilerine yöneltirler. Sonuç olarak, bu kişiler kendi eksiklik ve hatalarıyla orantısız bir biçimde kendilerine nefret beslerler (Freud, 1917). Bu düşünce kendine döndürme savunma mekanizmasına tekabül eder; depresif insanlar agresif hislerini kendilerine döndürme eğilimdedirler. Bu savunma mekanizmasının, çocuğun güvenilir olmayan bakıcısını gücendirmek istemediğinde oluştuğu sanılmaktadır. Çocuklar, bakıcısını gücendirmek istemez çünkü eğer böyle yaparlarsa bu davranışları için büyük bir bedel öderler, ayrıca başka güvenilir bir bakıcı kaynaklarından mahrumdurlar. Varlıklarını sürdürmek pahasına, insanlar çevrelerinde değişiklik yapacak güce sahip olamadıklarında hayati tehlike taşıyan koşul ya da durumu 
algılamamayı tercih edebilirler. Bunun yerine, bu insanlar olumsuz olaylar için kendilerine dönerler ve kendilerini suçlarlar. Depresif kişilerdeki devamlı hissedilen suçluluk ve suçlanmayı hak etme hissi bu yüzden bilinçli seviyede deneyimlenir ve bu hisler ego ile uyumludur. Ancak gerçekte suçluluk hissinin, öfke duygularının ifadesi olduğu belirtilir. Öfkenin suçluluğa dönüştürülmesi, öfkenin içe yönlendirilmesi; diğer bir deyişle, öfkeyi içe yönlendirilmesi ile gerçekleştirilir (McWilliams, 2010).

\section{Kişilik Organizasyon Çeşitleri ve Tanıya Olan Etkisi}

Psikanalitik biçimde tanı koymak için, kişilik organizasyonunun gelişimsel düzeyini belirlemek önemlidir çünkü bu savunma mekanizmaları, ego gücü, nesne ilişkileri ve yansıtma işlevinin seviyesini anlamayı sağlamaktadır (Gabbard, 2004).

Kişilik organizasyonunun belirlenmesinin önemli olmasının nedeni, bu organizasyonların terapötik müdahalenin odağı olabilecek konuları belirlemesidir. Hastanın problemin nedenini nasıl algıladığı, duygusal durumu, terapiye başvurma şekli, semptomların ego-uyumlu ya da ego-uyumsuz olması ve hastanın semptomları için gözlemleyen egosunun olup olmaması terapötik müdahalenin odağı olabilecek konulara örnek olarak verilebilir.

Psikanalitik görüşe göre üç çeşit gelişimsel kişilik örgütlenmesi vardır, Bunlar: (1) psikotik, (2) sınır durum, ve (3) nevrotik seviyelerdir. Bu seviyeler, Freud ve Erikson'un geniş çaplı teorik çalışmaları sonucunda ortaya çıkmıştır. Erikson'un psikososyal evreleri, çocukluktaki kişilerarası görevleri içermektedir (Feist \& Feist, 2008). Birinci evre, bağımlılık meseleleri ile ilgilidir: temel güvene karşı güvensizlik; ikinci evre ayrılma-bireyleşme meseleleri ile ilgilidir: otonomiye karşılık utanç ve şüphe ve çocukluğa denk gelen üçüncü evre ise kimlik belirleme ile ilgilidir: girişimciliğe karş1 suçluluk (Feist \& Feist, 2008). Psikotik seviye kişilik organizasyonu, ayrılma-bireyleşme sürecinden öncesi ile belirlidir ve bu seviyedeki insanlar kendi içinde olan ve dış dünyada bulunanları belirlemede zorluk çekerler. Sınır durum çeşidindeki kişilik ise yenilip yutulma düzeyinde iç içe ilişki ile travmatik olarak ayrılma içeren ilişkiler arasında bulunur. Nevrotik olarak organize kişilikler ise sevdikleri ve nefret ettikleri şeyler arasındaki mücadeleleri ile bilinirler (Gabbard, 2004; McWilliams, 2010). Psikotik türden organizasyon, diğer iki çeşit seviyeden gerçeklik testinin ve gözlemleyen egonun olmaması ile farklılık gösterir (McWilliams, 2010). Sınır durum kişilik, ilkel düzey savunma mekanizmaları kullanmaları nedeni ile nevrotik kişilik örgütlenmesinden ayrılır. Diğer bir deyişle, nevrotik olarak organize kişilikler bastırma ve karşıt tepki oluşturma gibi ikincil düzey savunma mekanizmaları kullanma kapasitelerine sahiptir; buna karşı1ık, hem sınır durum hem psikotik kişilikler yansıtmalı özdeşim ve idealizasyon gibi ilkel/birincil düzey savunma mekanizmaları kullanabilirler (Gabbard, 2004; McWilliams, 2010). Bu farklılıklar, terapistlerin farklı seviyedeki kişilik organizasyonları ile çalışırken farklı psikoterapi çeşitleri benimsemelerinin önünü açmaktadır. Üstelik terapötik ittifak kurma, terapötik ortamda karşılaşılan bariyer/dirençler ve terapistin hisleri değişik kişilik organizasyonları ile farkl1lık göstermektedir (McWilliams, 2010).

Sınır durum kişiliği olan bir hastanın regresyon savunma mekanizmasını kullandığı durumlarda psikotik emsallerinden ayrıştırılmaları zordur. Psikotik ve sınır durum kişilikler ilkel savunmalar kullanır gibi gözükseler de terapist savunma mekanizmalarının işlevselliğini yorumladığ 1 durumlarda sınır durum kişiliklerde kaygıda düşüş gözlenir. Ayriyeten, bu kişilerin kişiliklerini tarif etmeleri istendiğinde genel fikirler verdiği çünkü kişiliklerini nasıl tanımlayacaklarını bilmedikleri belirtilmiştir. Ayrılma-bireyleşme evresinde gerçekleşen problemler nedeni ile sınır durum kişiliklerin kendiliklerini algılamalarında temel bir eksiklikten muzdarip oldukları söylenmektedir. İkincil seviye savunma mekanizmaları kullanamamaları, belirsizlik ve çift-değerlilik toleranslarının olmaması yüzünden acı çekmektedirler ve bu sebeple psikoterapideki öncelikli amaçları acılarından kurtulmaktır (McWilliams, 2010). 
Sınır durum kişiliklerin gözlemleyen egolarının az gelişmiş olması sebebi ile terapistin yorumları kendilerine yöneltilen eleştiriler olarak algılanabilir. Bu durum tekrarlandığında terapötik ittifakın oluşumunda problem oluşturabilir. Ek olarak, terapist bir seansta iyi ve güçlü olduğu için övülürken, diğer bir seansta terapistin değersiz ve zayıf olduğu söylenebilir. Bunun karşılığında, karşı aktarım iki yönden birinde güçlü olur. Birincisi; terapistin ebeveyn gibi davranması; hastanın sevgi ve sıcaklık yoksunu olduğunu düşünmesi ve onlara ilgi göstermesidir. Diğer yön ise cezalandırıcı ebeveyn olmak gibidir; hastay1 manipülatif görmek ve sınırların gösterilmesi ihtiyacının hissedilmesidir (McWilliams, 2010).

\section{Kişilerarası Psikoterapi}

Anormal davranıştaki kişilerarası ilişkilere verdiği önemle Sullivan, klasik psikanalitik yaklaşıma, insanın kişiliğinin içinde yaşadığı kişilerarası dünyadan ayrılamayacağı şeklindeki fikri ile katkıda bulunur (Evans, 1996). Sullivan teorisinde bebeğin dünyadaki ilk deneyiminin, bebeğin kendini çevreden ayrıştıramadığı ve kendini küresel hissettiği protaksik mod olduğunu dile getirir. Bu modda, bebekler bazı gerilimler hissederler. Bunlar ihtiyaçların karşılanmaması durumunda ihtiyaçlar geriliminin hissedilmesi ve kaygının giderilememesi durumunda kaygı gerilimi hissedilmesidir. Birinci gerilime konu olan ihtiyaçlar açlık, susuzluk, sıcaklık, etkileşim ve işbirliği gibi kişilerarası ihtiyaçlar gibi fiziksel ihtiyaçlardır. İkinci gerilime ise kişilerarası ilişkilerdeki güven hissinin oluşturulamaması, diğer bir deyişle, ilişkilerdeki kaygının giderilememesi neden olur (Evans, 1996; Sullivan, 1953). İhtiyaçların doyurulması, bebeğin anneyi şefkatli ve sevecen olarak algılamasını sağlar. Sullivan (1953) annenin kaygısının, kaygıyı yatıştırma ya da giderme becerisi olmayan bebeğin kaygısını artırabileceğini belirtir. Eğer gerilim, anne tarafından giderilmezse bebek çaresiz ve zayıf hisseder. Kaygının uzadığı ve şiddetinin arttığı durum bebeğin uykulu kopmasına (somnolent detachment) neden olur. Bir başka ifadeyle, bebek kötücül ya da tepkisiz anneliğe cevap olarak kişiler arası ilişkiden kendini uykuya dalarak koparır. Sullivan (1953) uykulu kopmanın (örn. kayıtsılık) çokça kullanılmasının ciddi psikopatolojilerden sorumlu olabileceğini belirtmiştir.

Bebeğin annesiyle olan ilişkisinde rahatsı/kaygılı hissetmesi fikri ile Sullivan (1953) bağlanma teorisine atıfta bulunur ve insan yavrusunun kişisel ilişkiselliğinin altını çizer. Sullivan bu vurguyu, bağlanmanın anne ve bebek arasındaki yakınlığın sonucu olduğu kuramını ortaya koyan Bowbly'den farklı şekilde yapar (Bowlby, Robertson, \& Rosenbluth, 1952). Sullivan (1953) kişilerarası bağlılığın, bir bebeğin kaygısının yatıştırılmasına ihtiyaç duyduğu anda bu duruma annenin ne kadar duyarlı olduğu ile ilgili olduğunu öne sürer. Bağlanma teorisinin diğer önemli kurucularından Ainsworth (1982) bağlanmanın kalitesinin bebek-bakıcı etkileşimi ve aralarındaki duygusal uyum tarafından belirlendiğini öne sürerek Sullivan'ın fikirlerini desteklemiştir. Bebek bir öz-sistem geliştirerek kaygıyı yatıştırmaya ve gidermeye çalışır. Bu nedenle, öz-sistemin temel işlevleri kişilerarası güvenliği devam ettirmek ve kaygı üretme potansiyeli olan kişilerarası ilişkilerden kaçınmayı sağlamaktır.

Kendiliği ve geliştirilen simgeleri öğrenirken bebekler kişilerarası işbirliğini kullanırlar. Ödül, kaygı ve şiddetli kaygı anne ile kurulan kişilerarası işbirliğinin örnekleridir. Bebek, anneye işbirliği içinde davrandığı zaman anne bebeğin sosyalleşmesini sağlamak amacı ile bebeğe ödül verir (örn. gülümsemek) ya da bebekte kaygı oluşturur (örn. kaşları çatmak, bebekten gözlerini kaçırmak). Bu iki işbirliği yolu ile bebekler, örneğin gülümseme davranışını sergilemeyi öğrenir ve buna cevap olarak annenin sevecenliğini alır. Ancak annenin kaygısı sonucu bebekte şiddetli güvensizlik baş gösterebilir. Bu da bebeğin gelecek yaşamında psikopatoloji geliştirmesine neden olabilecek denli şiddetli bir kaygı olabilir. Bu öğrenme tecrübeleri “iyi-ben”, "kötü-ben” ve "ben-olmayan” öz-simgelerin gelişmesini sağlar. İlk öz-simge, iyi-ben, bebeklerin anneleri tarafından onaylandıkları ve ödüllendirildikleri davranışların içsel düzenlemelerinin bilişsel temsilleridir. İkinci öz-simge, kötü-ben, kaygının iç temsilidir; diğer bir ifade ile annenin bebeği onaylamamasına, şefkat kaybı (örn. kaşların çatılması) ve bağlanma kaybına neden olan davranışların içsel 
temsilleridir. Bu nedenle çocuklar ebeveyninin sosyal beklentilerine göre davranmayı öğrenirler ve kötüben deneyimlerinden kaçarak kaygıyı azaltmak için güvenlik manevraları geliştirirler. Sonuncu öz-simge, ben-olmayan, kötücül annelik sonucu uyanan şiddetli kaygıya neden olan bebek davranışlarının bilişsel temsilleridir. Ben-olmayan tecrübeleri, ciddi psikotik epizodlarda disosiyatif/çözülmeli deneyimlerle kaygıyı düşürme amacı ile ortaya çıkmaktadır (Evans, 1996; Sullivan, 1953).

Sullivan (1953) acımasız ebeveynlerin çocuklarının şefkat ve sevecenlik ihtiyacının kaygı ve acı getirebileceği inancını geliştirmelerine neden olabileceklerini belirtir. Bunun nedeni, çocukların şefkat ve sevecenlik ihtiyaçlarını dile getirdiği durumlarda acımasız ebeveynin şefkat ve sevecenlik yerine kaygı ve acı vermesidir. Kötücül ve güvensiz ebeveyn güvenlik, şefkat ve sevecenlik ihtiyacı içinde olan çocuğu incitebilir, ihmal edebilir ya da çocuğun bu ihtiyacı ile dalga geçebilir. Kaygılı ve utanmış hisseden çocuk, sevecenlik ve şefkat ihtiyacının zayıflık ve çaresizlik belirtisi olduğunu düşünebilir. Bu düşüncelerle çocuk, düşmanları tarafından sömürülmeye karşı kendinin korunmasız hale geldiğini düşünebilir.

Özetle, kişilerarası teori kaygıya olan hassasiyetin erken dönemde kurulmuş kişilerarası faktörlerin sonucu olabileceğini belirtir (Brown \& Harris, 1978). En etkili kişilerarası faktör samimi, sevecen ve güvenilir bir ilişkinin yokluğudur. Psikanalitik görüşe benzer şekilde, ebeveyn kaybı (Brown \& Harris, 1978) ve yetersiz ebeveynliğin (Parker, 1979) ergenlik ve yetişkinlikte depresyonun oluşumuna sebep olduğu gösterilmiştir. Kişilerarası Psikoterapi’ye (KPT) göre depresif kişiler çevreleri ile öyle bir etkileşime girerler ki hayatlarındaki önemli figürlerin desteğini kaybederek depresyonlarını destekleyecek geribildirimleri artırırlar (Coyne, 1976).

KPT'ye göre depresyon üç bileşene sahiptir (Mufson, Dorta, Moreau, \& Weissman, 2004). Birincisi, depresyon belirtilerinin psikobiyolojik ya da psikodinamik mekanizmaların baş göstermesi ile oluştuğu dönem olan semptom oluşumudur. İkinci bileşen, diğerleri ile sosyal etkileşim kurmayı içeren sosyal işlevselliktir. Bu etkileşimler güvenlik operasyonları ve iyi-ben simgelerinin oluşması gibi çocukluk dönemi deneyimlerinden türemektedir. Sonuncu bileşen süreğen davranışlar ve kişisel özellikler anlamına gelen kişiliktir. Kişilik; kaygı ve suçluluğa tepki verme, genel öz-güven ve işlevsellik tarzlarını içermektedir. KPT ilk iki bileşene müdahale etmek için geliştirilmiş olup süreğen kişilikte bir değişim yaratmayı amaçlamaz. Bunu başarmak için, KPT stratejileri, depresyonun kişilerarası alanında uzmanlık kazanması için hastaya olanak sunmaktadır. Bu amaçla, KPT'de psiko-eğitim verilmesine, duyguların açıklığa kavuşmasına, ailedeki rollerinin, arkadaşların ve toplumun rollerinin açıklığa kavuşmasına olanak tanınmaktadır. $\mathrm{Bu}$ stratejiler iletişim analizi, canlandırma, model olma ve kişilerarası problem çözme gibi tekniklerle gerçekleştirilmektedir (Klerman, Weissman, Rounsaville, \& Chevron, 1984; Weissman, Markowitz, \& Klerman, 2000).

KPT’nin ilk aşamasında semptomlar hakkında psiko-eğitim verilir, önemli kişilerarası ilişkiler araştırılır ve problemli alanlar belirlenir. Problemli alanlara; yaşam evreleri arasında geçiş sağlama, stres ile ve aile yapısındaki değişimlerle başa çıkma örnek verilebilir. KPT'nin orta evresinde terapist, kişilerarası zorlukların tartışılması için hastayı cesaretlendirir. Duygusal farkındalık geliştirmek ve ilişkilerde ve/ veya ailede yaşanan hayal kırıklıkları (örn. kötücük ebeveynlik) gibi duyguların ifade edilmesi iletişim becerilerinin iyileştirilmesi için çalışılmaktadır. KPT, gelecekteki depresif semptomlar hakkında bilgi verilmesi, orta evredeki başarılı stratejilerin değerlendirilmesi ve diğer ilişkilerde kişilerarası becerilerin teşvik edilmesi ile son bulur (Mufson, ve ark. 2004).

\section{Vaka ve Vaka Formülasyonu}

İlgili vaka, etik kurallar gereği takma isimle paylaşılacaktır. Kamil Bey 23 yaşında Mühendislik Fakültesinde öğrenim gören bir erkektir. Kamil Bey’in ailesi yurtdışında küçük bir kasabada yaşamaktadırlar. Kamil Bey ailesinin üçüncü çocuğudur. İlk iki çocuk ikiz olup biri Kamil Bey’in ablasıdır; 
diğeri ise annesinin uyuyakalması sonucu nefessiz kalarak ölmüş olan bir erkek bebektir. Kamil Bey sağlıklı büyümesi amacıyla çocukluğuna kadar çoğunlukla halaları ve babaannesi tarafindan bakılmıştır. Sonrasında Kamil Bey'in ebeveyn evine gitmesi için izin verilmiştir. Kamil Bey'in akrabaları ve ailesi kasabada birbirlerine çok yakın bir alanda yaşamaktadırlar ve hayatlarını bahçecilik ve tarımla kazanmaktadırlar. Kamil Bey ailesini, özellikle babasını muhafazakâr ve İslam'a düşkün olarak tanımlamaktadır. Kamil Bey babasının eleştirel ve otoriter olduğunu ifade etmiştir. Kamil Bey'in babası mimarlık mezunudur ancak mesleğini oturdukları kasabada gerçekleştirememiştir. Bu nedenle bir okulun kantini işletmektedir. Kamil Bey'in annesi ise hemşirelik mezunudur ancak hemşire olarak çalışmamaktadır. Ancak kasabalarında gerektiğinde bazı sağlık müdahalelerinde (örn. iğne vurmak, pansuman yapmak gibi) bulunur. Ebeveynler akrabaları ile özellikle yaz aylarında bahçecilik ve tarımdan da gelir sağlamaktadır.

Kamil Bey, babasının değişken biri olduğunu ve nasıl hissedip nasıl davranacağını anlamanın zor olduğunu dile getirmektedir. Babası Kamil Bey’in kendisi gibi olmasını ister ancak Kamil Bey dine karşı ilgili değildir, alkol ve sigara kullanmaktadır. Babasının önemli özelliklerinden biri diğer insanların ailesi ile ilgili olan görüşlerine değer vermesidir. Babası Kamil Bey’i diğer çocuklarla mukayese eder ve başarılarını değersizleştirir. Kamil Bey babasının fikirlerine karşı çıktığı zaman babası Kamil Beyi evden kovmakla tehdit eder ki bu Kamil Bey'in ergenlik döneminde üç kez yaşanmıştır. Kovulduktan sonra evine dönen Kamil Bey kötü ve değersiz hissetmiştir ve bunları unutmayacağını dile getirmiştir. Çocukken Kamil Bey kendinin bir yetişkin gibi bahçede çalışmasının beklendiğini belirtmiştir. Ağır ve uzun çalışma saatleri nedeni ile yorgun ve bitkin hissettiğini ifade etmiştir. Babasının beklediği gibi çalışamadığında, Kamil Bey’i babası döverek cezalandırmıştır.

Baba ile oğul arasında bir çatışma olduğunda, Kamil Bey’in annesi aracı rolü üstlenmiştir. Annesi genellikle oğlunu savunmaktadır ancak Kamil Bey annesinin aşırı koruyucu olduğunu belirtmektedir. Kamil Bey'in annesi ile özel bir ilişkisi vardır ve Kamil Bey annesinin isteklerini sorgulamadan kabul eder. Örneğin annesi onun Hatice ile nişanlanmasını istemiştir. Hatice, Kamil Bey’in annesinin arkadaşının kızıdır. Hatice'nin ailesi evlilik talep etmektedir ve Kamil Bey'in mezun olup en kısa sürede askere gitmesini istemektedirler. Kamil Bey annesinin isteğine uymuş ve Hatice ile nişanlanmıştır. Ancak Türkiye' de iken nişan yüzügü takmamaktadır ve mezuniyet süresini uzatmaktadır. Ek olarak, Kamil Bey Sibirya ya da Afrika'da çalışmaları olan bir şirkete çalışmak istemektedir. Kamil Bey'in annesine karşı gelmek istemediği ve kendi isteklerini feda edebileceği gözlenmiştir. Bu ilişkinin sembiyotik bir ilişki olabileceği düşünülmüştür.

Kamil Bey'in eğitim hayatı başarılı geçmiştir. Örnek vermek gerekirse, lise sınavlarında çok başarılı olan Kamil Bey ülkesinin büyük bir şehrinde yatılı bir kolejde eğitim almaya hak kazanmıştır. Öğrenciliğinde yaşadığı zorluklara bakıldığında Kamil Bey bir kez, on iki yaşındayken konsantrasyon problemi olduğunu ve doktorların beyin fonksiyonlarında çökme olduğunu belirtmiştir. Bu nedenle bir yıl kadar ilaç kullandığını ve iyileştiğini belirtmiştir. Diğer bir zorluk ise lisede yatılı öğrenim gördüğü sürede zengin öğrenciler ve yardımcı öğretmenlerle (belletmen) sorunlar yaşamasıdır. Zengin arkadaşlarıyla olan ilişkilerinde kendini küçümsenmiş ve değersiz hissettiğini dile getirmiştir. Yardımcı öğretmenlerle problemleri olduğunu söyleyen Kamil Bey, bunun öğretmenlerin öğrencilere çalışması için emir vermeleri ile ilgili olduğunu ifade etmiştir. Kamil Bey yatılı okulda yalnız hissettiğini belirtmiştir. Müdürlerinin uyarması üzerine anne ve babasının okula sadece bir kez ziyarete geldiğini hatırladığını da ifadesine eklemiştir.

Lisedeyken geceleri ders çalışan, çalışkan bir öğrenci olduğunu ifade eden Kamil Bey bunun uyku problemlerine neden olduğunu belirtmiştir. Kamil Bey mükemmel bir öğrenci olma standardını karşılayabilmek için çok sıkı çalışmıştır. Sonuç olarak fen bilimleri alanında ulusal bilim olimpiyatlarını kazanmıştır. Ülkesindeki üniversiteye giriş sınavını kaçıran Kamil Bey Türkiye'de öğrenim görmeye karar vermiştir. Bir kuruluştan üniversite eğitimi için zengin bir burs kazanmıştır. Üniversitede hazırlıktayken 
derslere gitmediğini, geceleri arkadaşları ile oyun oynadığını ifade eden Kamil Bey’in uyku düzeni bozulmuştur.

Kamil Bey 3.50 - 4.00 ortalama yapacak kadar zeki olduğunu ve akademik anlamda yüksek beklenti ve standartlarının olduğunu söylemiştir. Lisans programından ders almaya başladığında bu beklentisi karşılayamamıştır; başarı ve çabasının yüksek notlar alacak kadar yeterli olmadığını fark etmişstir. Zamanla notları düşmüş ve bölümünün zorunlu olan yüksek kredili derslerini tekrarlamaya başlamıştır. Sonuç olarak bir kuruluştan aldığı zengin burs kesilmiştir. Bunu telafi etmek amacı ile Kamil Bey özel ders vererek, bilgisayar tamiri yaparak ve geceleri sandviç satarak para kazanmıştır. Başarısızlık hissi ile mutsuz hissettiğini ifade eden Kamil Bey zamanla derslere gitmemiş ve hatta sınavları unutarak kaçırmaya başlamıştır. Sosyal olarak içe çekilen Kamil Bey kendini yurt odasına kapatmıştır. Uyku ve beslenme tarzı değişmiştir; gündüzleri uyumaya başlamıştır ve yetersiz beslenme nedeni ile kilo kaybetmiştir. Bu dönemde yoğun öfke hissetmiş ve belli bir nedeni olmaksızın insanlarla tartışma ve kavga etmeyi düşünmüştür. Zamanla yalnızlaşmış ve arkadaşları ile daha az iletişim kurmuştur. Kampusta geceleri gezmeye başlamış ve öfkesini yatıştırmak için ağaçları yumruklamıştır. Ara sıra ne yapacağını söyleyen bir ses duyduğunu dile getirmiştir. Sıklıkla kâbus görmüş ve terli bir şekilde uyanmıştır. Bu dünyaya ait olmadığını ve başka bir gezegene ait olduğunu düşünmeye başlamıştır.

KPT’nin belirttiği üzere, yetişkin ilişkilerinin kurulmasında erken dönem kişilerarası ihtiyaçlar önem taşımaktadır. Kamil Bey, dünyaya gelmesinin nedeninin abisinin ölümü üzerine ailesinin bir erkek bebek sahibi olmak istemesi olduğunu ifade etmiştir. Ebeveynleri gelecekte kendilerine erkek çocuğun bakacağını düşünmektedirler. Kamil Bey bu düşüncenin ülkesinde yaygın bir düşünce olduğunu ifade etmiştir. Dolayıs1 ile ailesi, kültürel değerlerden etkilenmiş ve ailenin devamlılığını sağlayacak bir erkek çocuğa sahip olmak istemiş gibi görünmektedir. Böylece, erkek bebeğin ölümünden bir sene kadar kısa bir süre sonra Kamil Bey'in annesi hamile kalmıştır. Annesinin bu dönemde yasta olduğu düşünülmüştür. Ek olarak, annesi, eşinin ailesi tarafından ilk erkek bebeğin ölümüne neden olduğu için suçlanmıştır. Doğumdan sonra Kamil Bey'in hala, teyze ve babaanne gibi birçok bakıcısı olmuştur. Bu bakıcıların her biri ihtiyaçlar gerilimini farklı düzeyde doyurmuş ve kaygı gerilimini farklı düzeyde rahatlatmış olabilir. Böylece, güvenilir ve sabit bir bakıcı ile kurulacak kişilerarası güvenlik sekteye uğramıştır. Sonuç olarak kaygıyı rahatlatan annenin yokluğuna bağlı olarak Kamil Bey kaygısını rahatlatacak içsel temsiller geliştirememiş olabilir. Uykulu kopma Kamil Bey’in bebekliğinde kaygıdan kaçınmak için etkin kullandığı bir yol olmuş olabilir. Bu açıklama Kamil Bey'in bir yer ya da insana güvenli bağlanma kurmasının zor gelmesini izah edebilir niteliktedir. Bu görüşü destekleyecek şekilde, Volkan ve Itzkowitz'in (2008) çok anneli bir evde yetişmenin erkek çocuklarının psikolojilerinin gelişimi üstüne etkilerini inceledikleri yazısı örnek verilebilir. Yazarlar, düş kırıklığı yaratan "kötü” anne ve kendisini yatıştıran başka bir "iyi”" annenin olduğu durumların, çocuğun annesinin gerçek kimliğini kabul etme sürecini olumsuz açıdan etkilendiğini ifade etmişlerdir. Yazarlara göre, çocuğun, annesinin kendisine ve hareketlerine karşı olan "iyi” ve "kötü" tavırlarını algılaması gereklidir. Aksi takdirde, çocuğun annesine ait "hayal kırıklığı" ve "hoşnutluk" veren imgelerini zihninde kaynaştıramayacağı ve çift değerliliğe toleransının oluşamayacağını öne sürmüsslerdir (Volkan \& Itzkowitz, 2008). Bu bilgi Kamil Bey'in çoklu annelik deneyimleri ve sonrasındaki sınır durum kişilik örüntüsü ile tutarlı görülmektedir.

Kamil Bey'in çocukluğunda ise (5 yaş sonrası) annesi bakımını üstlenmiştir. Bu dönemde değişmeyen bir bakıcının olması ve bakıcının tepkilerinin değişkenlik göstermemesi bebeğin iç güvenliğini sağlamış olabilir. Tutarlı bir şekilde olmasa da, annesi bebeğine ödül ve kaygı eğimi sağlamıştır olduğu düşünülmüştür. Böylece Kamil Bey öz-sistem ve simgeler oluşturmuştur. Bu nedenle, annesi oğlunun iyiben simgesini temsil etmiş olabilir. Sabit bir bakıcı ile kişisel olarak ilişki kurarak Kamil Bey annesine aşırı bir bağlanma hissetmiş ve annesinin depresyon ve kaygıya karşı hassas olmak gibi özelliklerini paylaşmış ya da içselleştirmiş olabilir. 
Öz sistemlerin oluşumu döneminde kaygıya neden olan diğer bir kaynak Kamil Bey’in babasıdır. Babası Kamil Bey’e bir erkek olarak değer vermiş ve ondan bahçede bir yetişkin gibi sıkı çalışmasını beklemiştir. Oğlundan beklentileri, oğlunun yaşı gereği kapasitesinin ötesindedir. Babasının beklentilerini karşılayamayan Kamil Bey, bu durumdan üzüntü duymasına rağmen zayıf olmakla suçlanmış ve dayakla cezalandırılmıştır. Babası, acımasız ebeveynlik örneği göstererek, Kamil Bey’in kötü-ben ve ben-olmayan iç temsillerinin oluşumunu ve dolayısı ile şiddetli kaygı ve güvensizlik hislerini desteklemiş olabilir.

Ciddi ve kaygı uyandırıcı bir talep, bireyin baş etme becerilerinin limitlerini zorladığı durumda, bu talep karşılanamaz. Böyle bir durum karşısında Kamil Bey kendisinin cezalandırılması gerektiğini hissettiğini ifade etmiştir. Bu benzeri hislerle karşılaştığında Kamil Bey disosiyatif/çözülmüş hissedebilir ve psikotik seviyede semptomlar oluşabilir.

Bu türden yaşantılar Kamil Bey’in şikâyetlerindeki yüksek kaygı, içe çekilme, başkalarının ona zarar vereceği inancı, sesler duyması, bu dünyaya ait olmadığı şeklindeki düşünceleri gibi psikotik semptomları da açıklayabilir.

KPT’ye göre duyguların ifade edilmesi erken dönem kişilerarası ilişkiler tarafından şekillendirilir. Duyarsız, sömürücü ya da kötücül ebeveynliğin çocukların ihtiyaçlarını ve duygularını ifade edememesini açıkladığı öne sürülmektedir. Teoriye göre kötücül ebeveynler çocuğun hassasiyet ve şefkat ihtiyacını görmezden gelirler. Çocuklar da şefkat ihtiyacını dile getirmenin şefkattense kaygı ve gerilim getirdiğine inanırlar. Böylece, çocuklar kırılganlıklarını ve ihtiyaçlarını yansıtmakta zorluk geliştirirler. Kamil Bey’in vakasında babasının talepkâr ve cezalandırıcı ebeveynlik sergilemesi ve erkek çocuklarının güçlü olmasını beklemesi nedeni ile Kamil Bey sıcaklık ve şefkat ihtiyacının bir zayıflık olarak algılandığını anlamış olabilir. Bu sebeple, yardım isteme ya da olumsuz duyguları paylaşmak gibi kendini zayıf gösterecek türden davranışları göstermekten kaçınmış olabilir.

Kamil Bey'in depresif semptomları lisans eğitiminde oluşmuştur. İngilizce eğitim veren bir üniversitede eğitim alma zorluğuna ek olarak başka bir kültürde olmanın ve yeni bir yerde güvensiz hissetmenin zorlukları da eklenmiştir. Kamil Bey'in baş etme stratejileri yeni çevrenin taleplerini karşılayamamış olabilir ve Kamil Bey çaresiz hissetmiş olabilir. Kötü-ben simgesinden kaçamadığı ve iyiben simgesine göre güvenli hissedemediği için yoğun kaygıya maruz kalmış olabilir. Kaygı ve güvensizlik duyguları tarafından baskılanmış şekilde Kamil Bey, bir tür psikopatoloji geliştirmiş olabilir. Psikotik semptomları geliştirme nedenlerinin kişilerarası bakış açısı ile açıklanabileceği düşünülmüştür. KPT'nin uygulanması depresif semptomlar ve sosyal işlevselliğe müdahale etmeyi amaçlar. Ancak hastaları depresyona açık hale getiren kişilik özelliklerine müdahale edilmez. Bunun telafi edilmesi için psikanalitik görüş tarafından açıklanan kişilik organizasyonları KPT'ye entegre edilmiştir.

Kamil Bey'in psikotik seviyede olduğu düşünülen semptomları; sosyal içe çekilme, ilişkilerde azalma, rahatsız ve depresif hissetme, performansta azalma, başkalarının ona zarar vereceği inancı gibi sanrılar ve sesler duymayı içeren varsanılardır. Ancak Kamil Bey’in gerçeklikten tam anlamı ile kopmadığı gözlenmiş̧ir.

Majör depresif bozukluk tanısı aldıktan sonra psikiyatristi tarafından Kamil Bey’e Depakin (antiepileptik) ve Zyprexa (antipsikotik) ilaçları verilmiştir. Kamil Bey reçetelendirilen ilaçları (Depakin ve Zyprexa) kullanmış ancak ilaçların terlemeye neden olan ve uyku düzenini bozan yan etkilerinden şikâyetçi olmuştur. Bu nedenle ilaçlarına uyum sağlayamadığını ve düzensiz kullandığını ifade etmiştir. Bir yıl kadar sonra psikiyatristinin tavsiyesini almıştır. Psikiyatristi, semptomlarının azalması nedeni ile ilaçları kullanmayı bırakabileceğini belirtmiştir. Kamil Bey’in sanrı ve varsanı gibi ciddi semptomlarının psikotik bir bozukluğun sonucu olmadığı düşünülmüştür. Algılarının gerçeklikten tamamen kopmadığı, sanrı ve varsanılarının zaman limitli olduğu ve ilaç tedavisi ve psikoterapi ile bu semptomların azaldığı bilgisi edinilmiştir. 
Bu semptomların ortaya çıkmasının ardında yatan neden Kamil Bey’in sınır durum organizasyonlu kişiliği sonucu olmuş olabilir. Örnek vermek gerekirse, sınır durum organizasyonlu kişiliğe sahip olanlar gerçeklik testi yapabilirler, diğer bir deyişle algıları gerçeklikten tamamen kopmaz. Buna ek olarak, bu kişilerin kullandıkları savunma mekanizmaları olgun değildir ve gözlemleyen egodan yoksundurlar. Diğer bir deyişle, dış dünyayı olduğu gibi algılayabilirler ancak aşağılık duygusuna neden olan ilkel savunmalar kullanırlar ve semptomlarına dışarıdan nesnel olarak bakamazlar, böylelikle semptomları ego ile uyumludur. Kamil Bey'in vakası sınır durum organizasyonu olan hastanın aşırı stres ve kaygı karşısında psikotik organizasyonu olan emsallerinden ayrılmasının zor olduğu şeklindeki önermeye uyduğu düşünülmektedir (McWilliams, 2010).

\section{Tedavi Süreci ve İyileşmenin Değerlendirilmesi}

Kamil Bey'in psikoterapisi Şubat 2012'de başlamış ve Mayıs 2014'te sona ermiştir. Eylül 2013 ve sonrasında görüşmeler iki haftada bir gerçekleştirilmiştir. Kamil Bey’in görüşmeleri terapist süpervizyon alırken gerçekleştirilmiştir. Bu bilgi kendisiyle bilgilendirilmiş onam formu ile paylaşılmıştır. Genel olarak Kamil Bey seanslarını düzenli olarak takip etmiş ve görüşmelere saatinde gelmiştir.

İlk yılda Kamil Bey psikiyatriste gitmiş ve ilaç kullanmıştır. Sesler duyma gibi semptomları düzenli takip edilmiştir. Kamil Bey 12 yaşında beyin işlevinde problemler olduğunu ifade etmiş̧tir. Psikotik semptomların organik nedenlerden ötürü olup olmadığının kontrolü için nöropsikolojik test bataryası terapist tarafından uygulanmıştır. Saat çizme testi (Agrell, \& Dehun, 1998), Standardize Mini Mental Test (Folstein, Folstein, \& McHugh, 1975), Bender-Gestalt Görsel Motor Testi (Bender, 1938), Benton Görsel Bellek Testi (Benton, 1945) sonuçları herhangi bir bozulmaya işaret etmemiştir. Test sonuçları için Tablo 1'e bakılabilir. Ayrıca Kamil Bey ilaçlarını düzenli kullanmamasına ve bir yıl sonra psikiyatristinin onayı ile ilaçlarını bırakmasına rağmen sanrı ve varsanıları azalmıştır.

Tablo 1. Nöropsikolojik Test Bataryası Sonuçları

\begin{tabular}{|c|c|c|c|c|}
\hline Test Adı & $\begin{array}{c}\text { Toplam Test } \\
\text { Skoru }\end{array}$ & $\begin{array}{l}\text { Klinik Kesme } \\
\text { Skoru }\end{array}$ & $\begin{array}{c}\text { Kamil Bey'in } \\
\text { Skoru }\end{array}$ & Sonuç \\
\hline $\begin{array}{l}\text { Saat Çizme } \\
\text { Testi }\end{array}$ & 5 & En az 3 & 5 & $\begin{array}{l}\text { Klinik kesme } \\
\text { skorunun } \\
\text { üstünde: normal }\end{array}$ \\
\hline $\begin{array}{l}\text { Standardize } \\
\text { Mini Mental } \\
\text { Test }\end{array}$ & 30 & $\begin{array}{l}\text { Eğitimliler için } \\
\quad \text { en az } 25\end{array}$ & 29 & $\begin{array}{l}\text { Klinik kesme } \\
\text { skorunun } \\
\text { üstünde: normal }\end{array}$ \\
\hline $\begin{array}{l}\text { Bender-Gestalt } \\
\text { Görsel Motor } \\
\text { Testi }\end{array}$ & 201 & En fazla $50-70$ & 47 & $\begin{array}{l}\text { Klinik kesme } \\
\text { skorunun } \\
\text { altında: normal }\end{array}$ \\
\hline $\begin{array}{l}\text { Benton } \\
\text { Görsel } \\
\text { Hafiza Testi }\end{array}$ & Değişebilir & $\begin{array}{l}\text { Yetişkinler için } \\
\text { en fazla } 0-2\end{array}$ & 1 & $\begin{array}{l}\text { Klinik kesme } \\
\text { skorunun } \\
\text { altında: normal }\end{array}$ \\
\hline
\end{tabular}


Terapist semptomların doğasını anlamaya çalışmış ve Kamil Bey’in belirli bir neden olmaksızın sıkıldığını ve öfkelendiğini gözlemlemiştir. Kamil Bey diğer insanlarla kavga etmek istediğini belirttiğinde terapist ona, dur-düşün-davran çalışmasını önermiştir. Kamil Bey’in öfkeli davranışlarını, görüşmeye tartışma amacı ile getirmesi için teşvik edilmiştir. Terapist, Kamil Bey’in olası şiddet içerecek davranışlarını ve olumsuz ilerlemenin sonuçlarına işaret ederek Kamil Bey'in bu türden davranmak istediği durumları o anda gerçekleştirmemesi konusunda anlaşmaya varmaya çalışmıştır. Kamil Bey bu teknikten yararlanmıştır, kimse ile kavga etmemiş ve yanında taşıdığı bıçağını yurt odasında bırakmıştır. Terapötik ittifakın gelişmesi amacı ile empatik dinleme ve yargılayıcı olmayan bir tutum sergilenmeye sağlanmış, eleştiri ve reddedici olabilecek yorumlardan kaçınılmıştır. Terapistin her haftaki görüşmelerde danışanı bekleyen sabit tutumu, danışanın annesinin karşılayamadığı ihtiyacı karşılamış olabileceği düşünülmüştür. Benzer bir şekilde, eleştirmeyen, reddetmeyen ve şefkatli olan tutum ise danışanın babasının karşılayamadığı ihtiyacı karşılıyor olabilir.

Şikâyetleri incelendiğinde, Kamil Bey hayatın genel olarak sıkıcı olduğunu ve böylece hep canının sıkıldığına inanmaktadır. Durum, düşünce ve duygular arasındaki ilişkiye dikkat çekmek için Bilişsel Davranışçı Terapi (BDT) tekniklerinden yararlanılmıştır (Fennell, 1988). Zorlayıcı ebeveynlik gibi erken dönem yaşantılar, "ben aşağılık bir insanım", "mükemmel olmalıyım yoksa insanlar beni hakir görür” gibi işlevsel olmayan varsayımlar belirlenmiştir. Üniversitede başarısız olmanın kritik olay olduğu kararlaştırılmıştır. Kamil Bey’in "her şeyi berbat ettim”, “eski güzel günlere dönüş yok”, "hiçbir şey değişmez", "hayattaki kontrolümü kaybettim" ve "her zaman yalnızım” şeklinde aşırı genelleme içeren olumsuz otomatik düşünceleri vardır. Bu düşünceler birçok depresif semptom ile ilişkilidir. Ancak, Kamil Bey'in semptomlarını gözlemleyememesi ve semptomlarını kendi karakterine atfetmesi, BDT ile yürütülen terapi sürecine sekte vurmuştur. Bu nedenle, KPT müdahaleleri kullanılmaya başlanmıştır.

Görüşmeler devam ettikçe, Kamil Bey erkek kardeşinin ölümü üzerine doğduğunu dile getirmiştir. Bu olayla ilgili olan düşünceleri sorulduğunda Kamil Bey yaşanan kaybın ardından ailede yama gibi hissettiğini ifade etmiştir. Annesinden bunu öğrendikten sonra kendisini mutsuz ve üzüntülü hissettiğini dile getirmiştir. Gömülmüş hatırların su yüzüne çıkması için terapötik ittifakın gelişmesi gerekmiştir. Kişilerarası ilişkiler, KPT teknikleri ile çalışılmıştır. Bu çalışmalar esnasında Kamil Bey babasının zorlayıcı tutumlarından bahsetmiş ve babasının kendisini kabul etmediğini hissettiğini dile getirmiştir. Babasının davranışlarını anlamakta zorluk çektiğini anlatmıştır. Babasının kendisini akranları ile karşılaştırdığında ve babasının kendisini küçük gördüğünde stresli hissettiğini ifade etmiştir. Tartışmalarından sonra, üç kez kendisini evden kovan babasına gücendiğini fark etmiştir. Yine de, babasına karşı olan hisleri tam olarak çözülmemiştir çünkü kendisini büyüttüğü için babasına minnet duyduğunu ve ona saygısını içselleştirdiğini belirtmiştir. Bu noktada, Kamil Bey, babasına duyduğu minnet yüzünden öfkesini kendine döndürmüş görünmektedir. Kendine döndürme savunma mekanizması depresif semptomlarla ilişkili görülmektedir (McWilliams, 2010). Bu nedenle, Kamil Bey babasına karşı olan hislerini açı̆̆a çıkardıkça, öfke duygulanımı azalmıştır. Eş zamanlı olarak, arkadaşları ile daha sık sosyal ilişki kurmaya başlamıştır.

Annesi ile olan ilişkileri ilerleyen seanslarda odaklanılan konulardan birisidir. Kamil Bey annesi ile olumlu bir ilişkisinin olduğunu ifade etmiştir. Diğer bir yandan da, annesinin gerçeği göremediğini dile getirmiştir. Bunun anlamı sorulduğunda babası ile tartıştıklarında annesinin her zaman yanında olduğunu söylemiştir. Diğer bir deyişle, Kamil Bey bir şekilde annesinin aşırı koruyucu tutumunu fark etmiştir ancak annesine olumsuz duygular atfetmek istememiştir. Örneğin, Kamil Bey annesinin aşırı koruyuculuğunu anlamlandıramadığını söylemiştir. Annesinin bu tür davranışlarının nedeninin, ilk oğlunun kaybının ardından sağlamak istediği telafi hissine atfetmemiştir. Bu durumun nedeni olarak, Kamil Bey’in çift-değerliliğe toleransının düşük olması olduğu düşünülmüş̧ür. Kamil Bey iyi-ben öz-simgesini temsil eden annesine olumsuz özellikler yakıştıramamıştır. 
Ek olarak, Kamil Bey annesinin iyi-ben tarafı olduğunu ve onunla iç içe geçmiş bir ilişkiye ihtiyaç duyduğunu kabul etmiştir. Örneğin, annesini kırmamak için Hatice ile nişanlanmayı kabul etmiş ancak nihayetinde Hatice'nin ailesinin beklediği gibi memlekete dönmektense yurtdışında çalışmak istediğini fark etmiştir. Annesinin taleplerine bağlı kalmasının kendisini sınırladığını ve kendi isteklerini feda ettiğini fark etmesine rağmen, hiçbir karşı harekette bulunmamıştır. Sınır durum kişilerin ayrılma-bireyleşme evresinde sorun yaşamaları sebebi ile (McWilliams, 2010), annesinden bağımsız kararlar almak ve aksiyona geçmek Kamil Bey’e çok zor ve kaygı uyandırıcı gelmiş olabilir. Bu ayrıca Kamil Bey’in mezuniyet sonrası yurtdışında çalışma isteğinden ve bununla çelişen şekilde memleketinden bir kız ile nişanlanmak gibi kendisini memleketine çağıran çabalarını açıklayabilir.

BDT'ye benzer şekilde KPT psiko-eğitim, duyguların açığa çıkarılması, aile ve aile rollerinin, arkadaşlarla ve toplumla olan sosyal aktivitelerin tanımlanmasının önemini vurgular. Görüşmeler esnasında Kamil Bey, semptomlarının kendi karakteri nedeni ile olduğunu ifade ettiği dikkati çekmiştir. Örneğin, karakteri farklı olduğu için farklı bir gezegene ait olduğunu düşündüğünü dile getirmiştir. Buradan hareketle, Kamil Bey’e semptomları hakkında psiko-eğitim verilmiştir (Klerman ve ark. 1984). Semptomların kritik olaylarla ve erken dönem yaşantılarla olan ilgisi gösterilerek yeniden çerçevelendirilmiştir. Buna ek olarak, bu yaşantıları ile ilgili duyguları ele alınmıştır. Görüşmelerde temel duygular çalışması yapılmıştır ve Kamil Bey bu duyguları ilk defa duyuyormuş gibi tepki vermiştir. Duygulanımı sorulduğunda, Kamil Bey sıklıkla "boşluk ve can sıkıntısı" hissettiğini ifade etmiştir. Sorgulamalar yolu ile boşluk ve can sıkıntısı hissinin ne anlama gelebileceği ele alınmış ve Kamil Bey bu hissin öfke olduğunu düşündüğünü ifade etmiştir. Öfke duygusu gündeme alındığında Kamil Bey öfkesinin aslında kırılganlığı ile ilgili olduğunu fark etmiştir. Bu çalışmalar esnasında ebeveynine kırgın hissettiğini ve öfkelendiğini dile getirmiştir; hatta kendisinin alıngan bir yapısının olabileceğini ifade etmiştir.

Yapılan görüşmelerde danışanın sosyal becerilerindeki değişimler gözlenmiş ve bu değişimler kendisiyle paylaşılmıştır. Yurttan dışarı çıkma ve arkadaşı ile kahve içme, arkadaşı ile sinemaya gitme gibi davranış ödevleri verilmiştir ve görüşmelerde tartışılmıştır. Görüşmelerin sonlarına doğru Kamil Bey, eşli danslar kulübüne yazıldığını ve burada birçok arkadaş edindiğini söylemiştir.

Görüşmelere dâhil edilen başka bir konu ise iletişimdir. Kamil Bey, örneğin, sınıftaki bir öğrenciden arkadaş olmamaları yüzünden not istemeye utanmaktaydı. İletişimin sözel, sözel olmayan ve bağlamsal çeşitleri Kamil Beyle çalışılmıştır. Kamil Bey’in iletişiminin memleketinden olan arkadaşları ile sınırlı olduğu çünkü onlarla konuşmaya başlarken güvenli hissettiği anlaşılmıştır. Eski arkadaşlarla iletişim kurma, yeni arkadaş edinme, sosyal aktiviteler organize etme gibi etkinlikler canlandırma ve model olma ile kolaylaştırılmıştır (Klerman ve ark. 1984).

Yapılan çalışmalar arasında iletişim analizi de yer almaktadır. Kamil Bey ile çevresi ile kurduğu ilişkilerindeki tarzı ele alınmıştır. Bu çalışmada, kendisinin stresli ve kaygılı hissettiği durumlarda ego savunmaların düştüğü izlenimi edinilmiştir. Bu nedenle de Kamil Bey’in kendini alıngan hissettiği ortaya çıkmıştır. Diğer bir ifade ile Kamil Bey eleştirildiğini, dalga geçildiğini ya da gücendirildiğini hissettiği zaman kaçıngan bir başa çıkma sergilemekte, yani, iletişimden kendini çekmektedir. Böyle zamanlarda öfkelenmiş gibi görünse de aslında kırılmış olan Kamil Bey, KPT'deki uykulu kopmaya benzer bir şekilde kendisini ortamdan çözmüştür. Bu iletişim tarzı görüşmelerde de kendisini göstermiştir.

İletişim tarzının belirlenmesi ile duygulanımın farkında olunmaması ve ego savunmalarının olgun olmaması arasındaki ilişki fark edilmiştir. Söz gelimi kırgın hisseden Kamil Bey bu hissini sinirlilik olarak algılamakta ve bu gibi ortamlarda çözülme yaşamaktadır. Bunun üzerine duygu çalışmaları ile birlikte savunma süreçlerine değinilmiştir. Kopup gitme- çözülme gibi bir deneyimin hangi his üzerine yaşanmış olabileceği, bu his yaşandığında başka türlü bir başa çıkmanın mümkün olup olmadığı, bu tür savunmaları kullanıp kullanılamayacağı gibi konular gündeme alınmıştır. 
Seanslarda gözlemlenen örneklerden birisi şu şekildedir. Görüşmelerde sorulan “Acaba siz de orada öfkeden başka bir duygu hissetmiş olabilir misiniz?" benzeri bir soru Kamil Bey'in duraksamasına, uzun süre düşünmesine ve sonrasında "hayır o şekilde değildi, o can sıkıntısıydı" şeklinde cevaplar vermesine neden olmaktaydı. Duygu farkındalığı ile birlikte Kamil Bey ilişkilerinde daha güçlü savunmalar kullanmaya başlamıştır. Örneğin, öfkelendiğini eşzamanlı fark edebilen Kamil Bey bunu arkadaşlarına uygun bir dille ifade etmeye başlamıştır. Bu gibi örnekler ego bütünleşmesi açısından Kamil Bey ciddi bir yol kat ettiğini gösterir niteliktedir.

Aktarım ilişkisi açısından, Kamil Bey'in annesi ve terapisti arasında karşılaştırma yapması anlamlı ve gelişen terapötik ilişkinin göstergesi olarak değerlendirilmiştir. Kamil Bey çocukken hasta olduğunda annesinin kendisine iğne vurduğunu söylemiştir. Buna benzer şekilde terapist, seans içerisinde aynalama, yeniden çerçevelendirme ya da yorum yapma gibi becerilerini kullandığında Kamil Bey "iğnelendiğini”" hissettiğini ifade etmiştir. Annesi ile olan ilişkisinde iğne somut iken ikincisinde iğne soyuttur. Bunun nedeni düşünüldüğünde, sınır durum organizasyonu ve az gelişmiş gözlemleyen ego nedeni ile, terapistin yorumları “iğneleyici” ya da eleştirel olarak algılanmış olabilir (McWilliams, 2010). Ancak ilerleyen seanslarla birlikte, Kamil Bey, kişilerarası ilişkideki benzerliği fark edecek denli olgunlaşmıştır ve terapide güvenli, desteklenmiş ve rahatlamış hissettiğini ifade etmiştir.

Görüşmelerde dikkati çeken diğer bir nokta ise Kamil Bey’in ailesi ile olan ilişkisindeki farkındalığını destekler niteliktedir. Kamil Bey'in ebeveyni ile olan ilişkisini tanımlamak için bir metafor kullanmıştır. Kamil Bey kendisinin, ailesindeki bir meyve ağacı olduğunu söylemiştir. Eğer meyve verirse ailesinde değerli olduğunu ancak vermezse değersiz olduğunu dile getirmiştir. Bu Kamil Bey'in gözlemleyen egosunu güçlendirdiğini göstermektedir. Ayrıca, bahçede bir ağaç gibi hissetmesi Kamil Bey’in ebeveyni ile yakın ilişki içinde kalmaya olan ihtiyacını temsil etmiş olabilir. Meyve vermesinin babasının ondan somut beklentilerini ve üretkenliğine bağlı olarak babasının onayını ve kabulünü kazanma yolunu temsil etmiş olabilir.

\section{Psikoterapötik Çıkarımlar}

Bebeklikte deneyimlenen kayg1, kişilerarası teorideki temel konudur (Sullivan, 1953). Annenin duyarlılığı, sıcaklığı ve sevecenliği bebeğin gelecekte psikolojik bozukluklar geliştirmesi anlamında koruyucu faktörlerdir. Annenin duyarlılığının olmadığı durumlarda, çocukların kaygılarını yatıştıracak stratejilerle donanımlı olmamaları nedeni dolayısıyla çocuklar, anneleri ile sağlıklı ve güvenli bir bağ kuramayabilirler. Buna ek olarak eğer bu çocukların ebeveyni zorlayıcı ve kötücül olarak davranırlarsa, çocuk sevecenlik ve şefkat isteğini göstermemeyi öğrenir ve kaygı ile başa çıkma mekanizmaları azalır. Erken dönem kişilerarası ilişkilere bağlı olarak, kişiler gelecekte samimi ve güvenilir bir ilişkilerinin olmadığı zamanlarda kaygıya yatkınlık geliştirebilirler (Parker, 1979). KPT, bu temelde, depresyon gibi psikolojik bozuklukların semptom oluşumu ve sosyal işlevsellik alanlarına müdahale etmeye çabalamaktadır. Depresif hastaların semptom seviyesini düşürmeyi ve sosyal işlevselliğini artırmayı amaçlar. Ek olarak, psikopatolojinin gelişiminde kişiliğin etkisini kabul etmesine rağmen, ona müdahale etmez (Mufson ve ark. 2004). Böylelikle, neden bazı insanların ciddi psikopatoloji geliştirirken, diğerlerinin nevrotik semptomlar geliştirdiği sorusunun cevaplanması için KPT için bütünleştirici bir partnere ihtiyaç duyulmuştur. Psikanaliz kişilik organizasyonları hakkındaki teorik yaklaşımı ile bu sorunun cevaplanmasına yardımcı olur. Gerçeklik testi, savunmaların olgunluğu ve gözlemleyen egoyu ölçüt olarak kullanarak üç çeşit kişilik organizasyonu olduğunu öne sürer. Bu kişilik organizasyonları en çok ciddiden, en az ciddiye göre sıralandığında; psikotik, sınır durum ve nevrotiktir. Sınır durum organizasyonu az gelişmiş gözlemleyen ego ve ilkel savunmaların kullanılması ancak gerçeklik testinin sürdürülmesi ile kendisini tanımlamaktadır. 
Kamil Bey'in vakasında, kendisinin üniversiteye gelmesi ve çevrenin zorlayıcı talepleri ile karşılaşması üzerine ciddi kaygı yaşadığı gözlenmiştir. Samimi ve doyurucu bir ilişkisinin olmaması nedeni ile kaygısını rahatlatamamış olabilir. Başarısız oldukça bir kısır döngü oluşmuştur; daha çok kaygı ile yüzleşmiş, başa çıkamamış ve nihayetinde psikotik semptomları olan bir tür depresyon geliştirmiştir. Sınır durum organizasyonlu bir kişiliğinin olması nedeni ile depresyonunun psikotik düzeydeki özelliklerle eşlik edildiği düşünülmüştür. Psikoterapide Kamil Bey’in terapistle güvenli bir bağ kurduğu izlenimi edinilmiştir. Semptomlarının takip edilmesiyle birlikte kaygılı duyguları azalmıştır, öz sistemi güçlendirilerek kayg1 üretme potansiyeli olan kişilerarası ilişkiler ve durumlarla baş etme becerilerinin geliştiği gözlenmiştir. Bunlara eşlik eder şekilde, sosyal ilişkileri takip edilmiştir ve zamanla artırılması amaçlanmıştır. Kamil Bey akademik hayatında iyileşme olduğunu, olumsuz duygularında azalma olduğunu ve arkadaşları ile olan işbirliğinin arttığını terapi sonucu olarak dile getirmiştir. 


\section{Kaynaklar}

Agrell, B., \& Dehun, O. (1998). The clock-drawing test. Age and Ageing, 27, 399- 403.

Ainsworth, M. (1982). Attachment: Retrospect and prospect. In C. M. Parkes \& J. Stevenson-Hinde (Eds.) The Place of Attachment in Human Behavior (pp. 3-30). New York: Basic Books.

American Psychiatric Association. (2000). Diagnostic and statistical manual of mental disorders (DSM-IVTR) (4th ed., text rev.). Washington, DC: American Psychiatric Publishing.

American Psychiatric Association (2013). Diagnostic and statistical manual of mental disorders (5th ed.). Washington DC: American Psychiatric Publishing.

Bender, L. (1938). A visual motor geştalt test and its clinical use (Research Monograph No.3). New York: American Orthopsychiatric Association.

Benton, A. L. (1945). A visual retention test for clinical use. Archives of Neurology and Psychiatry, 54(3), 212-216. doi:10.1001/archneurpsyc.1945.02300090051008

Bowlby, J., Robertson, J., \& Rosenbluth, D. (1952). The two-year-old goes to the hospital. The Psychoanalytic Study of The Child, 1, 82-94.

Brown, G. W. \& Harris, T. (1978). The social origins of depression: A study of psychiatric disorders in women. New York: Free Press.

Coyne, J. (1976). Towards an interactional description of depression. Psychiatry, 39 (1), 28-40. doi:10.1521/00332747.1976.11023874

Evans, F. B. (1996). Harry Stack Sullivan: Interpersonal theory and psychotherapy. London: Taylor \& Francis.

Feist, J., \& Feist, G. J. (2008). Theories of personality (7th ed.). United States America: The McGraw-Hill Companies, Inc.

Fenichel, O. (1945). The psychoanalytic theory of neurosis. New York: Norton.

Fennell, M. (1988). Depression. In K. Hawton, P. M. Salkovskis, J. Kirk, \& D. M. Clark (Eds.). Cognitive behavior therapy for psychiatric problems: A practical guide (169-234). Oxford: Oxford Medical Publications. 169234

Folstein, F. F., Folstein, S., \& McHugh P. R. (1975). Mini-mental state: A practical method of grading the cognitive state of patients for the clinician. Journal of Psychiatry Research, 12(3), 189-198.

Freud, S. (1917). Mourning and melancholia. The Standard Edition of the Complete Psychological Works of Sigmund Freud, Volume XIV (1914-1916): On the History of the Psycho-Analytic Movement, Papers on Metapsychology and Other Works. London: The Hoghard.

Gabbard, G. O. (2004). Long term psychodynamic psychotherapy: A basic text. Washington DC: American Psychiatric Publishing.

Klerman, G. L., Weissman, M. M., Rounsaville, B. J., \& Chevron, E. (1984). Interpersonal psychotherapy for depression. New York: Basic Books.

McWilliams, N. (2010). Psikanalitik tanı (Klinik süreç içinde kişilik yapısını anlamak) (E. Kalem, Çev.) İstanbul: İstanbul Bilgi Üniversitesi.

Mufson, L., Dorta, K. P., Moreau, D., \& Weissman, M. M. (2004). Interpersonal psychotherapy for depressed adolescents (2nd ed). New York: The Guildford.

Oltmanns, T. F., \& Emery, R. E. (2006). Abnormal psychology (5th ed). New Jersey: Pearson.

Parker, G. (1979). Parental characteristics in relation to depressive disorders. British Journal of Psychiatry, 134, 138-147. doi: 10.1192/bjp.134.2.138

Plante, T. G. (2005). Comtemporary clinical psychology (2nd ed). New Jersey: John Wiley and Sons Inc. 
Sullivan, H. S. (1953). The interpersonal theory of psychiatry. New York: W.W. Norton \& Company. Volkan, V., \& Itzkowitz, N. (2008). Ölümsüz Atatürk. İstanbul: Bağlam.

Weissman, M. M., Markowitz, J. C., \& Klerman G. L. (2000). A comprehensive guide to interpersonal psychotherapy. Albany, NY: Basic Books. 


\section{Summary \\ Interpersonal Therapy and Integration of Different Personality Organizations: A Review of a Major Depressive Disorder Case}

Major depressive disorder is characterized by behavioral, affective, cognitive and somatic symptoms. Nowadays, medical approach for mental disorders is given importance in classification systems; however, to fully comprehend the reasons of the symptoms, early life experiences should unfold. Interpersonal therapy (IPT) focuses on early life period and puts a great emphasis on the dynamics of anxiety. The first interpersonal relation, mother-infant attunement, has profound effect in coping with anxiety. IPT speculates that the mother could be capable of relieving tension of anxiety and satisfying tension of needs in a child. If this cannot occur or occur in malevolent ways, the infant is expected to develop detachment, which may lead to psychological disorders in later life. The severity of symptoms in a patient is also associated with the enduring personality characteristics; however, IPT avoids it. Personality organization types in psychoanalytic approach are integrated to compensate for the avoidance of IPT regarding personality. Accordingly, there are neurotic, borderline and psychotic personality organizations. Borderline organized ones may behave similar to psychotic ones if they face with severe anxiety. A case with major depressive disorder coupled with psychotic symptoms is reviewed in the current study. The case is presented with the effects early life events and current critical incidences. Formulation and treatment course are elaborated in light of the integration of two theories. Lastly, the implications are discussed.

Keywords: Major depressive disorder, Interpersonal psychotherapy, Personality organization 